\title{
Towards an Integrated Ecosystem-based Bioaccumulation and Metal
}

Speciation Model

\section{Short title: An Ecosystem-based Bioaccumulation Model}

Russell G. Richards ${ }^{1 \mathrm{a}}{ }^{*}$, Milani Chaloupka ${ }^{2 \mathrm{~b}}$, Rodger Tomlinson ${ }^{3 \mathrm{a}}$

a Griffith Centre for Coastal Management, Griffith University, Gold Coast, Queensland 4222, Australia

b Ecological Modelling Services Pty Ltd, PO Box 6150, University of Queensland, St Lucia, Queensland 4067, Australia

*Corresponding Author: Fax: +61 (0)7 555 28067, Ph: +61 (0)7 555 28520, r.richards@griffith.edu.au

${ }^{1}$ RR - conceived and designed study, performed research, analysed data, contributed model and wrote the paper

${ }^{2} \mathrm{MC}$ - conceived and designed study, performed research, analysed data, contributed model and wrote the paper

${ }^{3} \mathrm{RT}$ performed research, analysed data and assisted in writing the paper 


\begin{abstract}
Heavy metal bioaccumulation models are important for interpreting water quality data, predicting bioaccumulation in organisms and investigating the provenance of contaminants. To date they have been predominantly used as single-issue models, under steady-state conditions and in isolation of the biogeochemical processes that control bioaccumulation. Models that incorporate these processes would allow a more holistic approach to bioaccumulation modeling and contaminant assessment, however this has been rarely undertaken, probably because it requires the integration of interdisciplinary areas. In this study, we have developed such a model that integrates three key multi-disciplinary areas (biological, metal speciation and bioaccumulation processes) and responds to variations in temporal external and internal forcing. Furthermore, spatial context is provided by developing the model within a simple hydrodynamic box-modeling framework. The calibrated model was able to predict with reasonable accuracy the temporal and spatial trends of soft-tissue copper bioaccumulation in a coastal oyster. This exploratory model was also used to highlight the importance of phytoplankton as an important vector of copper uptake dynamics by an oyster, therefore reinforcing the importance of the integrated approach. Finally, our model provides a framework for greater application beyond this specific example such as in the areas of waterway restoration, which has been shown to be an important area of ecological and environmental research.
\end{abstract}

Key words: Bioaccumulation, oysters, copper-speciation, heavy metals, ecosystem model, Moreton Bay, restoration 


\section{INTRODUCTION}

Oysters and other aquatic filter-feeding organisms are commonly used as 'sentinels of the environment' because of their ability to provide time-integrated and easily measurable concentrations of heavy metals in the aquatic environment. However, a key challenge for decision makers and natural resource managers is how to interpret this biomonitoring data in the context of understanding and managing water quality, ecological health and pollutant provenance.

Copper, which is one of the most ubiquitous and pervasive aquatic contaminants, is found in coastal waters and sediments throughout the world (Eisler 1998). While copper is an essential trace element for the normal growth of molluscs (White and Rainbow 1985), human activities are causing copper to be discharged into coastal waterways at a rate that is significantly greater than the natural geological rate (Phillips 1980). The resulting elevated copper concentrations has been shown to have toxic effects on biota (Brand and others 1986) including oysters, which at times have turned green from excessive exposure (Chon-Lin and others 1996).

Bioaccumulation models are a commonly-used tool for interpreting existing water quality data and for predicting bioaccumulation in target organisms (Wang and others 1996). The widespread use of biokinetic-based bioaccumulation models (Wang and others 1996; Reinfelder and others 1997; Luoma and Rainbow 2005; Goulet and others 2007) that interweave physiological rates of biota within a mechanistic framework has made bioaccumulation modeling more predictive and flexible. 
It is becoming increasingly evident that the effectiveness and relevance of such contaminant assessments are improved when they are considered holistically, in the context of dynamic biogeochemical processes and in terms of spatial and temporal variability (Paquin and others 2002; Kim and others 2008; Monte and others 2009b). However, it has been commonplace to neglect the interactions and feedback processes between food webs, nutrients and toxicant cycles and take a reductionist approach by applying them in isolation from the overall system as single-issue models (Koelmans and others 2001).

The difficulty in developing dynamic ecosystem-level models is in coupling 'interdisciplinary' models within the same framework (He and others 2001). For bivalve filter-feeders (e.g. oysters and mussels), which have been the focus of several metal bioaccumulation studies (e.g. Wang and others 1996; Reinfelder and others 1997), the combined and explicit roles of biological interactions and metal speciation are often neglected, although this is often because emphasis is on determining model parameters using laboratory-based techniques such as radioisotope analysis (Wang and others 1996; Reinfelder and others 1997). However, it is well known that the transport, fate and bioavailability of heavy metals is reliant on individual metal species (Moffett and others 1997), which highlights the importance of a more integrated approach.

Currently, the studies by Kim and others (2008) and Monte and others (2009b) are rare examples of an integrated modeling approach to quantifying heavy metal bioaccumulation in aquatic organisms. In the mesocosm study of Kim and others (2008), time-varying mercury (Hg) speciation and key ecological processes 
(phytoplankton and zooplankton growth) were intertwined and ultimately contributed to the bioaccumulation of $\mathrm{Hg}$ in a clam (Mercenaria mercenaria). Similarly, Monte and others (2009b) presented a model (MOIRA) that could couple the physical, abiotic and biotic processes controlling heavy metal concentrations for a lake environment. Further examples of integration are exemplified by the biotic ligand model (BLM; Di Toro and others 2000), which provides a framework for coupling metal speciation with bioaccumulation by including biological receptors of an organism (e.g. at the fish gill) amongst the complexation reactions. It is noted that the BLM is more applicable to toxicity assessments (e.g. Paquin and others 2002), does not incorporate an eutrophication (phytoplankton dynamics) component and is restricted to dissolved uptake pathways (Goulet and others 2007).

The aim of this paper is to develop and present an ecosystem-based approach to modeling copper bioaccumulation in a common coastal oyster (Saccostrea glomerata) by coupling together three key multi-disciplinary areas of research, specifically a biological model that accounts for phytoplankton dynamics, a copper speciation model and a bioaccumulation model. Spatial context is provided by developing this model within a box-modeling framework. The systems approach is emphasized by the inclusion of catchment loading of nutrients and copper as well as seasonal meteorological forcing on the water column itself, an area not explicitly explored in the study by Kim and others (2008). The model is calibrated against water quality and biomonitoring data collected from a 12-month field-based monitoring program carried out as part of the study.

\section{SITE DESCRIPTION}

The domain for the ecosystem model is Moreton Bay (153 $12^{\circ}$ E, $27^{\circ} 18^{\prime}$ S), a wave 
dominated semi-enclosed embayment located in southeast Queensland, Australia (Figure 1). It has a surface area of approximately $1,500 \mathrm{~km}^{2}$, an average depth of 6.3 m (Eyre and McKee 2002) and exchanges water with the ocean mainly through a northern passage between Moreton Island and the mainland (Gabric et al. 1998).

\section{MODEL DESCRIPTION}

The ecosystem-based bioaccumulation (EBB) model presented here couples together a biological model, copper speciation model and a bioaccumulation model (Figure 2). The entire model was coded within R (Ihaka and Gentleman 1996; R Development Core Team 2009), an open-source software environment for statistical computing and graphics.

For each time step (1 day), the time-varying concentrations of total copper $\left(\mathrm{Cu}_{\mathrm{T}}\right)$, phytoplankton and particulate organic matter (POM) are calculated and inputted into the speciation model. The concentrations of various functional groups of copper species are then calculated and subsequently used as inputs to the bioaccumulation model where the soft-tissue copper concentration in the biomonitoring organism is calculated.

\section{Box-Model Framework}

Spatial resolution is provided through using a box-modeling approach where the water body is divided into specific sections or regions (boxes). Each box is assumed to be well mixed both horizontally and vertically and with exchange occurring at the interface of adjacent boxes and oceanic boundaries. These exchanges are modeled using the product of an exchange rate $\left(\rho_{i}\right)$ (Dowd 1997) and the concentration gradient between the box of interest $(Q)$ and an adjacent box or boundary $\left(Q_{0}\right)$ : 


$$
\text { Exchange }=\rho_{\mathrm{i}} \times\left(\mathrm{Q}_{0}-\mathrm{Q}\right)
$$

We have restricted the spatial element of the model to two boxes to reduce the calibration data requirements.

\section{Biological Sub-Model}

A biological sub-model of the EBB model quantifies the dynamics of interaction between phytoplankton biomass, dissolved inorganic nitrogen (DIN), particulate organic nitrogen (PON) and particulate organic matter (POM). DIN is included under the assumption that Moreton Bay is nitrogen limited as highlighted by Dennison and Abal (1999). It is also assumed here that the oysters do not influence the concentrations of phytoplankton, DIN, POM or PON through their filtration and excretion processes.

Nitrogen is cycled within the water column via phytoplankton (growth/mortality), PON (mortality/mineralization/POM) and DIN (mineralization/growth). External exchanges with the water column are incorporated in the model through oceanic exchange (phytoplankton, PON, POM and DIN), settlement/resuspension (POM and PON) and catchment loading (DIN).

Environmental forcing occurs through temporal changes in solar irradiance (light), water temperature and wind speed.

Phytoplankton concentration is modeled as being dependent upon a maximum growth rate constant $\left(\mu_{\max }\right)$ that is adjusted for the multiplicative effects of light $(f I)$, nutrient 
availability $(f N)$ and temperature $(f T)$ :

$$
\mu=\mu_{\mathrm{MAX}} \times \mathrm{fN} \times \mathrm{fI} \times \mathrm{fT}
$$

where $f N$ is calculated using a Michaelis-Menton function (3) with $k_{D I N}$ representing the half saturation constant for nitrogen uptake $\left(\mathrm{mg}-\mathrm{N} \mathrm{m}^{-3}\right)$.

$$
\mathrm{fN}=\frac{\mathrm{DIN}}{\mathrm{DIN}+\mathrm{k}_{\mathrm{DIN}}}
$$

The light limitation function, fI, is based on Steele's (Steele 1962) equation (4), where $I$ is the surface light intensity, $I_{k}$ is the half saturation light intensity, $z$ is the water depth and $\lambda$ is the light extinction coefficient.

$$
\mathrm{fI}=\frac{\mathrm{I}}{\mathrm{I}_{\mathrm{k}}} \times \exp (-\lambda \times \mathrm{z})
$$

To account for the effects of algal self-shading, the light extinction coefficient, $\lambda$, is modeled as a function of phytoplankton concentration using the Riley equation (see Shigesada and Okubo 1981) with $\lambda_{0}$ representing the background extinction coefficient, $\lambda_{\text {Chla }}$ is an extinction coefficient due to chlorophyll-a and $\alpha_{0}$ is a factor for converting phytoplankton biomass (as $\mathrm{N}$ ) to chlorophyll-a:

$$
\lambda=\lambda_{0}+\lambda_{\text {Chla }} \times \alpha_{0} \times \text { Phy }
$$


1985), where $\theta$ is a temperature adjustment coefficient and $T_{R E F}$ is the reference temperature $\left(20^{\circ} \mathrm{C}\right)$ :

$$
\mathrm{fT}=\theta^{\left(\mathrm{T}-\mathrm{T}_{\mathrm{REF}}\right)}
$$

Phytoplankton mortality $(m)$ is calculated using a quadratic function (7), primarily because it is considered to give more realistic behaviour than constant specific mortality rates (Murray and Parslow 1999). $m_{0}$ is the background mortality rate at $20^{\circ} \mathrm{C}, m_{1}$ is the maximum grazing loss rate at $20^{\circ} \mathrm{C}$ and $K_{P}$ is the phytoplankton biomass that corresponds with the maximum grazing rate.

$$
\mathrm{m}=\mathrm{m}_{0}+\frac{4 \times \mathrm{m}_{1} \times \text { Phy }}{\left(\mathrm{K}_{\mathrm{P}}+\mathrm{Phy}\right)^{2}}
$$

Mineralization controls the loss rate of PON and the gain rate of DIN and is modeled using a temperature-dependent rate constant (8), where $\min _{20}$ is the temperature referenced rate:

$$
\min =\min _{20} \times \mathrm{fT}
$$

A trigonometric function (9) is used to provide temporal trends for and solar irradiance where $\bar{T}$ is the annual average value for the environmental parameter, $T_{R}$ is annual the range, $t$ is Julian day and $t_{\text {lag }}$ represents the phase difference, where $t_{\text {lag }}$ is the calibrated parameter. 


$$
\mathrm{T}=\overline{\mathrm{T}}+\left(\frac{\mathrm{T}_{\mathrm{R}}}{2} \times \sin \frac{\left(2 \times \pi \times\left(\mathrm{t}+\mathrm{t}_{\mathrm{lag}}\right)\right)}{365.24}\right)
$$

Exchange between the sediment and the water column is based on the critical depth of mixing $\left(L_{C}\right)$ that is driven by surface wind speed $(U)$ (McEwan 1996). If $L_{C}$ is less than the depth of the water column (z) then the model assumes that particulates (POM and PON) settle out of the water column at a prescribed velocity. Conversely, if $L_{C}$ exceeds $z$, then the model assumes that resuspension is the dominant exchange process (settling is assumed to cease) and that particulates are resuspended at a constant velocity from the sediment.

$$
\mathrm{L}_{\mathrm{C}}=\frac{2.07 \times \mathrm{U}^{1.5}}{\sqrt{\mathrm{z}}}
$$

Under calm (low wind) conditions, POM and PON are assumed to settle out of the water column at a constant settling rate. For stronger winds, if $L_{C}$ exceeds the water column depth, then it is assumed that settling stops and resuspension of POM from the sediment occurs at a constant rate. It is assumed that a fixed fraction of the POM that is resuspend contributes to the PON budget.

Finally, while POM and PON are modeled separately, they do contribute to the budget of each in the sub-model. PON that is generated (phytoplankton mortality) or lost (mineralization) is respectively added to, or subtracted from, the POM budget.

\section{Copper Speciation Sub-Model}

A simple copper speciation sub-model was developed to quantify the distribution of 
different bioavailable copper species. This sub-model separates the total aqueous copper concentration $\left(\mathrm{Cu}_{\mathrm{T}}\right)$ into the broad functional groups of dissolved and particulate phases (Figure 1), which are conventionally defined here by their ability to pass through (dissolved), or be retained by, (particulate) $0.45 \mu \mathrm{m}$ pore-size filter paper. The dissolved $\left(\mathrm{Cu}_{\mathrm{D}}\right)$ and particulate $\left(\mathrm{Cu}_{\mathrm{P}}\right)$ phases are further separated into inorganic and organic groups, as well as the cupric ion $\left(\mathrm{Cu}^{2+}\right)$. The particulate phase includes inorganic particles, which are represented by hydrous ferric oxides (HFO) (Dzombak and Morel 1990), particulate organic matter (POM) and phytoplankton. A homogenous model (González-Dávila and others 1995) is used for each particulate type and assumes that there is a maximum number of binding sites that remains constant and independent of $\mathrm{pH}$ and also assumes that all available binding sites have equal affinity for copper adsorption.

The main inputs into the speciation model are the time-varying concentrations of POM and phytoplankton calculated from the biological sub-model and $\mathrm{Cu}_{\mathrm{T}}$, which is modeled as a state variable dependent on external loading into Box $1\left(\mathrm{Cu}_{\mathrm{LOAD}}\right)$, vertical exchange with the sediment and horizontal exchange between the boxes and the ocean. $\mathrm{Cu}_{\mathrm{T}}$ exchange between the water column and the sediment follows the same principle as for POM and PON, whereby under calm (low wind) conditions, copper is assumed to settle out of the water column and for stronger winds, the direction of settlement is reversed. Copper adsorbed to POM and HFO particulates, as calculated in the speciation sub-model, are assumed to represent the settling portion of $\mathrm{Cu}_{\mathrm{T}}$. No speciation calculations are carried out for the sediment, rather the copper is assumed to resuspend only as $\mathrm{Cu}_{\mathrm{T}}$. 
Copper speciation calculations are based on the method of principal components (Morel 1983) that requires all species involved in the speciation reactions to be written in terms of a set of primary species from which the remaining species can be derived. For example, if $\mathrm{Cu}^{2+}$ and $\mathrm{DOM}^{-}$are selected as principal components then $\mathrm{CuDOM}^{+}$can be determined based on the formation equation:

$$
\mathrm{Cu}^{2+}+\left[\mathrm{DOM}^{-}\right] \leftrightarrow \mathrm{CuDOM}^{+} \quad ; \mathrm{K}_{1}
$$

where,

$$
\mathrm{K}_{1}=\frac{\left[\mathrm{CuDOM}^{+}\right]}{\left[\mathrm{Cu}^{2+}\right]\left[\mathrm{DOM}^{-}\right]}
$$

Rearranging equation (12) in terms of $\mathrm{CuDOM}^{+}$gives:

$$
\mathrm{CuDOM}^{+}=\mathrm{K}_{1} \times \mathrm{Cu}^{2+} \times\left[\mathrm{DOM}^{-}\right]
$$

The total concentration of DOM, which is the sum of $\mathrm{DOM}^{-}$and $\mathrm{CuDOM}^{+}$, can then be calculated:

$$
\begin{aligned}
\mathrm{DOM}_{\mathrm{T}} & =\left[\mathrm{DOM}^{-}\right]+\mathrm{K}_{1} \times \mathrm{Cu}^{2+} \times\left[\mathrm{DOM}^{-}\right] \\
& =\left[\mathrm{DOM}^{-}\right] \times\left(1+\mathrm{K}_{1} \times\left[\mathrm{Cu}^{2+}\right]\right)
\end{aligned}
$$

Finally, $\mathrm{CuDOM}^{+}$can be written in terms of the principal components and the stability constant $\left(\mathrm{K}_{1}\right)$ by combining equations (13) and (14): 


$$
\mathrm{CuDOM}^{+}=\frac{\mathrm{K}_{1} \times\left[\mathrm{Cu}^{2+}\right] \times \mathrm{DOM}_{\mathrm{T}}}{1+\mathrm{K}_{1} \times\left[\mathrm{Cu}^{2+}\right]}
$$

Similar equations are also derived for the other unknown species including the adsorption species. Overall, nine principal components are used $\left(\mathrm{H}^{+}, \mathrm{Cu}^{2+}, \mathrm{Na}^{+}, \mathrm{Ca}^{2+}\right.$, HFO_OH, ALG , $^{-} \mathrm{OM}^{-}, \mathrm{DOM}^{-}, \mathrm{CO}_{3}^{-2}$ ) to estimate 25 chemical species involved in 16 reactions. The Davies equation is used to account for the non-ideal behaviour of the dissolved inorganic species in the seawater (Coale and Bruland 1988). For adsorption to particulate surfaces, temperature and electrostatic effects are ignored. Electrostatic effects have been ignored because the high ionic strength of the water shields electrical binding sites (Buffle and De Vitre 1993).

The concentrations of the various copper species are estimated using a modified Newton Rhapson root finding method (van der Lee 1998). This approach requires that a solution vector $(\mathrm{dC})$ is solved using Gaussian elimination (16), where $\mathrm{P}^{\prime}\left(\mathrm{C}^{\mathrm{m}}\right)$ is the Jacobian matrix consisting of derivatives of the total concentration estimates with respect to each variable, $\mathrm{E}\left(\mathrm{C}^{\mathrm{m}}\right)$ is the error vector representing the difference between the actual (known) and estimated total constituent concentrations and $r$ is a 'polishing factor' used to assist in convergence. $r$ is scaled depending on the distance from the root by comparing values of $\mathrm{dC}$ with their corresponding values of $\mathrm{C}$ (see van der Lee 1998:67).

$$
E\left(C^{m}\right)-r \times d C \times P^{\prime}\left(C^{m}\right)=0
$$

A critically-compiled (Martell and Motekaitis 1988) database of stability constants is 
used in the speciation model. These stability constants are summarised in Table 1.

\section{Bioaccumulation Sub-Model}

The oyster bioaccumulation sub-model employs a standard first-order kinetic model to quantify the copper bioaccumulation in the soft-tissue of the oyster:

$$
\frac{\mathrm{d}\left(\mathrm{C}_{\text {oys }}\right)}{\mathrm{dt}}=\left(\mathrm{k}_{\mathrm{u}(20)} \times \mathrm{fT} \times \mathrm{Cu}\right)-\left(\mathrm{k}_{\mathrm{e}} \times \mathrm{C}_{\text {oys }}\right)
$$

The first product on the right-hand side of equation (17) estimates the uptake of copper from ingested food, where $\mathrm{k}_{\mathrm{u}(20)}\left(\mathrm{l} \mathrm{g}^{-1} \mathrm{~d}^{-1}\right)$ is the uptake rate at $20^{\circ} \mathrm{C}$, fT is the temperature function (equation 6) (Richards and Chaloupka 2009) and $\mathrm{Cu}\left(\mu \mathrm{g} \mathrm{l}^{-1}\right)$ is the bioavailable copper concentration in the water. The second product in equation (17) represents the loss pathway of copper, where $\mathrm{k}_{\mathrm{e}}\left(\mathrm{d}^{-1}\right)$ is the elimination rate constant and $\mathrm{C}_{\mathrm{OYs}}\left(\mu \mathrm{g} \mathrm{g}^{-1}\right)$ is the dry-weight copper concentration in the soft-tissue of the oyster. $\mathrm{k}_{\mathrm{e}}$ is not modeled as a temperature-dependent variable because the metal efflux rate in marine organisms has been shown to be independent of temperature (Mubiana and Blust 2007).

The state equations for the 2-box EBB model are summarised in Table 2. These are based on the assumption that both boxes are subject to external catchment loads and that oceanic exchange occurs with Box 2 only.

\section{MATERIALS AND METHODS}

\section{Application of the Model}

The EBB model was applied to Moreton Bay (Figure 1) assuming drought conditions. 
The rationale for this is that the biomonitoring and water quality data used to calibrate the EBB model were predominantly collected during a prolonged dry period. Additionally, this approach simplifies the model by allowing an average nutrient loading rate to be assumed. It is acknowledged, however, that this does not allow for the impact of river floods to be included, which can be a major vector of contaminants into Moreton Bay (Simon 1989; Dennison and Abal 1999). Environmental perturbation is included in the model in the form of wind-driven resuspension, which is known to be a significant mechanism of contaminant dynamics in shallow estuaries like Moreton Bay (Dennison and Abal 1999).

Spatial plots of chlorophyll-a (Dennison and Abal 1999) were used to guide demarcation of the regions used in the box model (Figure 2) because phytoplankton is a known vector of trace metal bioaccumulation in filter feeders (Conti and Cecchetti 2003) and can also be a strong regulator of bioavailable copper (Liao and others 2002). These spatial plots highlighted a strong west-east (high - low) gradient with highest values in Deception Bay, Bramble Bay and Waterloo Bay along the northwestern shoreline and lower values to the east. Exchange rates $\left(\rho_{\mathrm{i}}\right)$ were approximated from residence times previously determined for the Bay (Dennison and Abal 1999) while the volume and mean water depth of each box was estimated from the geometry file of a calibrated two-dimensional hydrodynamic model (Bell and Amghar 2001).

Model parameters are summarised in Table 3. Local water temperature from the ecosystem health monitoring program (www.ehmp.org) and solar irradiance data from the Australian Bureau of Meteorology (www.bom.gov.au) were used to fit equation 
(9) while annual loading rates of TN estimated for Moreton Bay (Eyre and McKee 2002) were used to estimate daily DIN loading rates.

\section{Field Data}

A field-based monitoring program was implemented in Moreton Bay to provide calibration data for the EBB model. Two-year old oysters (Saccostrea glomerata) sourced from a local oyster lease were deployed at two locations (refer Figure 2) in the Bay over a 12 month period (2002-2003). At the time of deployment, five oysters were randomly selected from the total pool of oysters and retained for determination of initial soft-tissue copper concentration. Following this, five oysters were collected from each monitoring site each month and analysed for soft-tissue (dry weight basis) copper concentration. Single surface water samples were also collected during the biomonitoring period and analysed for total suspended sediment (TSS), volatile suspended sediment (VSS), particulate copper and dissolved copper. VSS is assumed here to represent the particulate organic matter (POM) concentration.

\section{Model Scenarios}

Five scenarios of the EBB model were run based on different configurations of the bioavailable fraction of copper. Scenario 1 assumed that this was restricted to copper adsorbed to phytoplankton (Cu-Phy), Scenario 2 assumed this consisted of $\mathrm{Cu}-\mathrm{Phy}$ and copper adsorbed to POM (Cu-POM), Scenario 3 assumed that the total pool of particulate copper $\left(\mathrm{Cu}_{\mathrm{P}}\right)$ was the bioavailable fraction, Scenario 4 assumed that the total pool of aqueous copper $\left(\mathrm{Cu}_{\mathrm{T}}\right)$ was the bioavailable fraction and Scenario 5 used only the cupric ion concentration $\left(\mathrm{Cu}^{2+}\right)$ to calculate uptake. 
The biological sub-model and $\mathrm{Cu}_{\mathrm{T}}$ concentrations were simultaneously fitted to the measured POM (this study), chlorophyll-a, DIN (EHMP 2008) and $\mathrm{Cu}_{\mathrm{T}}$ (this study) concentrations for the two boxes by adjusting background light extinction $\left(\lambda_{0}\right)$, background mortality rate $\left(\mathrm{m}_{0}\right)$, mineralization rate at $20^{\circ} \mathrm{C}\left(\mathrm{min}_{20}\right)$, settling rate, sediment resuspension rate and copper loading rate $\left(\mathrm{Cu}_{T, L O A D}\right)$. The copper speciation sub-model was calibrated to the $\mathrm{Cu}_{\mathrm{D}}$ concentrations measured in the two boxes by adjusting the global DOM concentration for Moreton Bay and using the measured concentrations of POM, chlorophyll-a and $\mathrm{Cu}_{\mathrm{T}}$ as inputs into the speciation submodel. The bioaccumulation sub-model was calibrated for each of the five scenarios against the biomonitoring data by adjusting the uptake $\left(\mathrm{k}_{\mathrm{u} 20}\right)$ and elimination $\left(\mathrm{k}_{\mathrm{e}}\right)$ rate constants.

\section{RESULTS}

\section{Biological Parameters}

The estimated concentrations of POM, chlorophyll-a and DIN (Figure 3) provided by the biological sub-model generally reflected the spatial patterns observed within Moreton Bay with higher concentrations in Box 1 (northwestern region of Moreton Bay) and lower concentrations in Box 2 (the rest of the Bay). Predicted chlorophyll-a concentrations (Figure 3a-b) agreed reasonably well with the temporal pattern of higher concentrations during warmer months and lower concentrations during the cooler months, especially for Box 1. While the predicted variability in chlorophyll-a for Box 2 also mimics the expected seasonal changes and falls within the data uncertainty bars, the magnitude of temporal change appears somewhat attenuated when compared to the data. 
Predicted DIN concentrations (Figure 3c-d) broadly agreed with the measured concentrations although there appears to be slight over-prediction for Box 2 (Figure 3d) when compared against the median values. It is also noticeable that the temporal variation is not well replicated for both boxes although the predicted values generally fall within the error bars.

There is broad agreement between predicted and measured POM concentrations (Figure 3f-g) although the temporal variability observed in the measured concentrations for POM is not observed in the predictions (Figure 3g). No error bars are available for this data as these are based on single measurements.

\section{Copper Speciation}

The performance of the speciation sub-model was assessed by comparing the predicted concentrations against those obtained using an established speciation package (PHREEQC ver2; Parkhurst and Appelo 1999). Input conditions, speciation equations and stability constants were the same for both models including the specification of copper complexation with particulates (phytoplankton, POM and HFO) as ionic exchange and the use of the Davies equation to account for non-ideal behaviour of the modelled species. An output summary (Table 4) indicates that the EBB speciation sub-model generally provided estimates of the various copper species that were consistent with those obtained using PHREEQC. The observed discrepancies between the two models are due to differences in the calculated activity coefficients. This was most evident for $\mathrm{Cu}^{2+}$ where the EBB sub-model estimated an associated activity coefficient $\left(\gamma_{\mathrm{Cu} 2+}\right)$ of 0.263 whereas PHREEQC estimated a value of 0.104 . Re-running the speciation sub-model with $\gamma_{\mathrm{Cu}+}$ set at 0.104 produces 
estimates that are near identical to the PHREEQC estimates. All copper speciation calculations successfully converged for all species within 16 iterations (convergence tolerance $=1 \times 10^{-15}$ ).

The predicted concentrations of $\mathrm{Cu}_{\mathrm{T}}$ for each box are comparable to the respective measured concentrations (Figure 4) although the apparent temporal variability in the measured data is not well replicated. The predicted speciation patterns across the two boxes highlight that copper speciation are dominated by complexation to DOM and absorption to POM and to a much lesser degree, adsorption to phytoplankton. The concentration of copper adsorbed to HFO material is ca. four orders of magnitude lower than associated with DOM and POM while the average cupric ion concentration estimated for Box 1 and Box 2 were 5.0e-14 M and 2.6e-14 M respectively.

\section{Copper Bioaccumulation}

The deployed oysters were characterized by obvious spatial and temporal trends in their soft-tissue copper (Figure 5). Those deployed near the mouth of the Brisbane River (Box 1) showed a clear bioaccumulation pattern with an initial rapid increase in

copper over the first ca. 120 days and reaching a maximum of ca. $320 \mu \mathrm{g} \mathrm{g}^{-1}$. Between days 120 - 280, the soft-tissue copper concentration remained reasonably constant before increasing again towards the end of the deployment period. Conversely, the oysters deployed within Box 2 did not show any discernable bioaccumulation and actually appeared to decrease (depurate) towards the end of the monitoring period.

The results of the bioaccumulation modeling indicated that all scenarios were able to generally replicate the temporal and spatial variability of the measured soft-tissue 
copper concentrations (Figure 5). The model slightly underestimated for Box 1 and overestimated for Box 2 and this was more noticeable when the copper uptake species were based on $\mathrm{Cu}_{\mathrm{T}}$ or $\mathrm{Cu}^{2+}$. Figure 6 presents comparisons of the predicted versus actual bioaccumulation copper concentrations for the five modeling scenarios and highlights that the most consistent predictions (with respect to the measured concentrations) are obtained for scenarios $1-3$. The poor alignment at higher $\mathrm{Cu}$ concentrations (Box 1) highlights the inability of the model to reflect the more rapid temporal changes in the bioaccumulation data. Figure 6 reaffirms the progressive underestimation (Box 1) and overestimation (Box 2) of bioaccumulated Cu especially for the higher ordered scenarios.

The uptake $\left(\mathrm{k}_{\mathrm{u}, 20}\right)$ and elimination $\left(\mathrm{k}_{\mathrm{e}}\right)$ kinetic rate constants for the five modeling scenarios are presented in Table 5 . The value for $\mathrm{k}_{\mathrm{u}, 20}$ obtained when the uptake pathway was restricted to $\mathrm{Cu}^{2+}$ is several orders of magnitude higher than obtained for the other scenarios. Values of $\mathrm{k}_{\mathrm{u}, 20}$ were similar for scenarios 2 and 3, and slightly lower for when the total copper pool $\left(\mathrm{Cu}_{\mathrm{T}}\right)$ was assumed to contribute to uptake. Conversely, values of $\mathrm{k}_{\mathrm{e}}$ were similar across all five scenarios.

\section{DISCUSSION}

\section{Integrating Speciation, Eutrophication and Bioaccumulation}

We have presented here an ecosystem approach to the dynamic modeling of copper bioaccumulation in a common biomonitoring species by integrating metal speciation, phytoplankton dynamics and oyster bioaccumulation within a dynamic temporal domain. The EBB model allowed the roles of phytoplankton as both a regulator of copper speciation and a mechanism of copper bioaccumulation to be included in the 
overall assessment. Historically, such modeling in marine environments has been applied in isolation from the overall system, often in controlled laboratory conditions and under steady-state conditions that do not reflect the dynamic changes that occur in the natural environment. It is clear that an ecosystem-based approach requires an integration of multi-disciplinary skills and this could be a contributing factor into the dearth of these types of models.

There is a paucity of existing models that couple heavy metal speciation with phytoplankton and bioaccumulation calculations, the study by Kim and others (2008) being a notable exception. In their model, they were able to assess the dominating role that sediment-bound mercury (Hg) played in controlling bioaccumulation in phytoplankton and subsequently the bioaccumulation in a filter-feeder (clam). However, the domain for their model was based on mesocosm experiments and therefore did not fully explore the effects of seasonal changes in forcing functions such as light, temperature and contaminant loadings through mechanisms such as wind-driven resuspension.

Monte and others (2009b) also presented an ecosystem model (MOIRA) that conceptually could predict the behaviour of heavy metals in freshwater systems through coupling hydrologic, abiotic and biotic processes together in a similar manner as presented here. Their explicit focus was on the environmental fate of radionuclides rather than heavy metals and therefore it is not clear how well their model assumptions and underlying model structure would transfer to metals, especially those metals with complex speciation characteristics such as copper. 
The biotic ligand model (BLM; Di Toro and others 2000) is another framework that integrates metal speciation and bioaccumulation. The BLM explicitly accounts for the concentration of the free-ion form of a metal (e.g. $\mathrm{Fe}^{3+}, \mathrm{Cu}^{2+}$ ), which is widely acknowledged as the most bioavailable and toxic form (Moffett and others 1997). The BLM, however, is constrained to modeling dissolved metal species, does not explicitly include dietary routes as an uptake pathway (Goulet and others 2007) and is more applicable to toxicity assessments because it focuses on metal chelation at specific sites (e.g. Paquin and others 2002). As indicated here and shown in other studies (Wang and others 1996; Reinfelder and others 1997; Luoma and Rainbow 2005, Goulet and others 2007), bivalves and other aquatic organisms can derive much, if not most, of their metal bioaccumulation from the particulate phase.

\section{Model Performance}

The model was calibrated by fitting it to a spatiotemporal dataset consisting of chlorophyll-a, POM, DIN, $\mathrm{Cu}_{\mathrm{T}}$ and oyster-copper data and adjusting a suite of EBB model parameters. The calibrated parameters observed here for background mortality rate (Bowie and others 1985; Chapelle and others 2000), background light extinction coefficient (Scott 1978; Lee and Rust 1997) and mineralization rate (Bowie and others 1985; Dowd 2005) and DOM (Hirose 1994) are consistent with other studies. The settling rate also compares favorably to some literature values (Dowd 2005) although it is an order of magnitude lower than for others (Chapra 1997). It is important to note that settling rate is an aggregated parameter that incorporates many influencing factors such as particle shape, size and density, the viscosity and density of the water itself along with the water column flow-field and therefore a range of values for this parameter is not unexpected. An implication of a lower settling rate (than might 
actually exist) would be underestimating the flux of copper to the underlying sediment.

The copper elimination rate constants, $\mathrm{k}_{\mathrm{e}}$, estimated for the five modeling scenarios are comparable to that previously observed for copper and oysters (Scanes, 1996; Lim and others 1998). Comparison of $\mathrm{k}_{\mathrm{u}}$ with literature is more problematic because it is inherently site-specific and typically not measured in many studies (Chang and Reinfelder 2000; Richards and Chaloupka 2009).

The performance of our model was highlighted by our ability to reflect the temporal trends in the bioaccumulation data with reasonable accuracy. In particular, the model was able to reproduce the general bioaccumulation pattern observed in the oysters deployed in Box 1, which was characterised by general stages of accumulation (days 1 - 100; 250 - 350), equilibrium (days 100 - 220) and depuration (days 220 - 250). This cycling between bioaccumulation, equilibrium and depuration probably reflects temperature-dependency in the physiological feeding responses of the oysters (Mubiana and Blust 2007; Richards and Chaloupka 2009), which is accounted for in the model, and reproduction cycle (Robinson and others 2005), which is not. The relative consistency in model fit, seemingly irrespective of the uptake pathway used (Table 5) is because the biaccumulation sub-model does not quantify the role of separate uptake pathways but rather aggregates them within a single rate constant. The accuracy of the model is then dependent on the values obtained for the kinetic rate constants, in particular $\mathrm{k}_{\mathrm{u}}$. As mentioned previously, it is problematic to compare $\mathrm{k}_{\mathrm{u}}$ with literature values because this parameter is so context-specific. This issue could be addressed by adopting a bioenergetic approach (Reinfelder and others 1997) that 
explicitly accounts for the physiological feeding responses (clearance and ingestion rate, assimilation/absorption efficiencies and pseudofaeces production rate) although this would greatly increase the parameterisation requirements of the sub-model. Modification of the model to a bioenergetic framework is seen as a natural progression in developing the model further.

The EBB model replicated the spatial gradient of bioaccumulated copper concentrations (refer Figures 5 and 6) with reasonable accuracy with higher concentrations predicted for Box 1 compared to Box 2. It was noticeable that the accuracy of the spatial representation declined when the copper uptake pathway was based on $\mathrm{Cu}^{2+}$ or $\mathrm{Cu}_{\mathrm{T}}$. Interestingly, the predicted spatial gradients for $\mathrm{Cu}\left(\mathrm{Cu}_{\mathrm{T}}, \mathrm{Cu}_{\mathrm{P}}\right.$ and $\mathrm{Cu}_{\mathrm{D}}$ ) appeared to be slightly accentuated compared to the measured data (Figure 4) but did not result in similarly accentuated spatial differences in the soft-tissue copper predictions (Figure 5). This is perhaps an indicator that the copper-uptake pathways adopted for scenarios 2-4 were not reflective of the actual dominant uptake pathways that were occurring. The poorest representation of the spatial gradient occurred when the uptake route was restricted to $\mathrm{Cu}^{2+}$ (scenario 5). For bivalves, bioaccumulation from direct uptake of $\mathrm{Cu}^{2+}$ will be limited because it is predominantly chelated to biologically inert dissolved organic matter (GonzálezDávila and others 1995). However, it is important to consider that the amount of copper associated with seston is influenced by the $\mathrm{Cu}^{2+}$ concentration and therefore indirectly controls particulate-phase uptake. The best agreement in the spatial and temporal trend occurred when the uptake pathway was restricted to phytoplankton only, which is consistent with the strong evidence that phytoplankton is the dominant mechanism for metal uptake in bivalves (Wang and others 1996; Reinfelder and 
others 1997).

Model predictions of the water quality indicators (chlorophyll-a, DIN, POM, $\mathrm{Cu}_{\mathrm{D}}$, $\mathrm{Cu}_{\mathrm{P}}$ and $\mathrm{Cu}_{\mathrm{T}}$ ) appeared somewhat mixed when compared against the measured values. Spatiotemporal predictions for chlorophyll-a compared favorably with the measured concentrations while DIN predictions predominantly fell within the error bands of the measured concentrations. However it is noticeable that the temporal variation in the measured concentrations of DIN, POM, $\mathrm{Cu}_{\mathrm{D}}, \mathrm{Cu}_{\mathrm{P}}$ and $\mathrm{Cu}_{\mathrm{T}}$ were not evident in the model output. We believe that the effects of numerical dispersion (Liao and others 2002) due to using two boxes to represent spatial resolution coupled with assigning constant boundary conditions for these variables are partly responsible for this. Dowd (2005) showed that far-field concentrations could be important in influencing pelagic state variables within a system. In our model we chose to use constant boundary conditions for simplicity and because of data availability. Our results should also be evaluated in the context of both the monitoring data and the exploratory nature of our model. As is previously stated, time series for $\mathrm{POM}, \mathrm{Cu}_{\mathrm{D}}, \mathrm{Cu}_{\mathrm{P}}$ and $\mathrm{Cu}_{\mathrm{T}}$ are based on single monthly surface-water measurements that were used to represent the conditions throughout the two boxes. These one-off measurements are therefore coarse representations of the ambient conditions within Moreton Bay and do not convey the variability of concentrations that were actually occurring.

Consistent with the objectives of our study of developing an ecosystem-based bioaccumulation (EBB) model, what we present here is a first iteration of that ongoing process. There is an obvious need to further develop the biochemical processes that are occurring in the sediment such as metal speciation and exploring 
the potential contribution of inorganic fines to the nutrient cycling. It also seems critical to improve the spatial resolution of the model, both vertically and horizontally, to reduce the effects of numerical dispersion and depth-averaging. The module-based method used here entails that other heavy metals could be incorporated with relative ease while the oyster bioaccumulation model could be refined to include greater representation of the physiological responses of the oyster itself, including its feedback impacts on copper (or other metal) and nutrient budgets. Finally, there is a need to obtain improved calibration data to compare the model predictions to.

\section{Further Application of the Ecosystem Model}

We have demonstrated our dynamic model by focusing on the interaction between copper, a common pervasive contaminant in many of the world's waterways (Eisler 1998), and oysters, one of the most commonly used biomonitoring organisms (Reinfelder and others 1997). The EBB model provides a framework for greater application beyond this specific example such as in the areas of waterway restoration (Jackson and others 2001). For example, our model could be used to address questions like 'how many oysters would be required to restore a system to some prior condition?' and ‘would nutrient addition to a contaminated system increase metal sequestration in the food chain and to the sediments?' The utility of this is demonstrated in Jackson and others (2001) who highlighted the historical importance of oysters in Chesapeake Bay to filter the entire water column every three days. Subsequent removal of oysters through harvesting led to algal blooms and siltation of the system. As our model focuses on heavy metal speciation, inherently it would be applied to situations of restoring systems contaminated by metals. However, it would be relatively straightforward to incorporate standard oyster feeding and growth 
dynamics (Casas and Bacher 2006) into the ecosystem model to account for particulate filtration.

\section{CONCLUSIONS}

The ecosystem-based bioaccumulation (EBB) model presented here successfully integrated the multi-disciplinary areas of metal speciation, eutrophication and bioaccumulation modeling. This model has also been developed so that predictions of metal bioaccumulation are made in response to dynamic temporal and spatial changes in the biogeochemical environment. Overall, the model was able to replicate actual water quality and biomonitoring data with acceptable accuracy both in the temporal and spatial domains and has strong potential for application in areas of waterway management such as restoration modeling.

\section{ACKNOWLEDGEMENTS}

We thank the CRC for Coastal Zone Estuary and Waterway Management for providing financial assistance. We are also grateful to the Ecosystem Health Monitoring Program (EHMP) project team for their help in providing access to EHMP water quality data. Finally we thank the comments of two anonymous reviewers who significantly strengthened this manuscript.

\section{REFERENCES}

Arhonditsis GB, Papantou D, Zhang W, Perhar G, Massos E, Shi M. 2008. Bayesian calibration of mechanistic aquatic biogeochemical models and benefits for environmental management. Journal of Marine Systems 73:8-30 
Bell S. Amghar M. 2001. Modeling scenarios for South East Queensland Regional Water Quality Management Strategy, Cooperative Research Centre for Coastal Zone, Estuary and Waterway Management. Technical Report 2.

Bowie GL, Mills WB, Porcella DB, Campbell CL, Pagenkopf JR, Rupp GL, Johnson KM, Chan PWH, Gherini SA, Chamberlain CE. 1985. Rates, constants, and kinetics formulations in surface water quality modeling (Second Edition). Environmental Research Laboratory Office of Research and Development U.S. Environmental Protection Agency.

Brand LE, Sunda WG and Guillard RRL. 1986. Reduction of Marine Phytoplankton Reproduction Rates by Copper and Cadmium. Journal of Experimental Marine Biology and Ecology 96: 225-250.

Buffle J and De Vitre RR. 1993. Chemical and Biological Regulation of Aquatic Ststems, CRC Press, Boca Raton.

Burton ED, Phillips IR, Hawker DW. 2005. Reactive sulfide relationships with trace metal extractability in sediments from southern Moreton Bay, Australia. Marine Pollution Bulletin 50:589-595.

Burton ED, Phillips IR, Hawker DW. 2004. Trace metals and nutrients in bottom sediments in the Southport Broadwater, Australia. Marine Pollution Bulletin 48:378384. 
Byrne RH, Miller WL. 1985. Copper(II) carbonate complexation in seawater. Geochimica et Cosmochimica Acta 49:1837-1844.

Casas S, Bacher C. 2006. Modeling trace metal (Hg and Pb) bioaccumulation in the Mediterranean mussel, Mytilus galloprovincialis, applied to environmental monitoring. Journal of Sea Research 56:168-81.

Chang SI, Reinfelder JR. 2000. Bioaccumulation, Subcellular Distribution, and Trophic Transfer of Copper in a Coastal Marine Diatom. Environmental Science and Technology 34:4931-4935.

Chapra SC (1997). Surface water quality modelling. New York, McGraw Hill 844pp

Chon-Lin L, Huei-Yi C and May-Yin C. 1996. Use of oyster, Crassostrea gigas, and ambient water to assess metal pollution status of the charting area, Taiwan, after the 1986 green oyster incident. Chemosphere 33(12): 2505-2532

Coale KH, Bruland KW. 1988. Copper complexation in the Northeast Pacific. Limnology and Oceanography 33:1084-1101.

Conti ME, Cecchetti G. 2003. A biomonitoring study: trace metals in algae and mollusks from Tyrrhenian coastal areas. Environmental Research 93:99-112.

Dennison WC, Abal E. 1999. Moreton Bay Study: A scientific basis for the healthy waterways campaign: South East Queensland Regional Water Quality Management Strategy, Brisbane. 
Di Toro DM, Allen HE, Bergman HL, Meyer JS, Paquin PR, Santore RC. 2000. The Biotic Ligand Model: A Computational Approach for Assessing the Ecological Effects of Metals in Aquatic Systems. International Copper Association Ltd. Published as part of the Environmental Program in a series on Copper in the Environment and Health.

Dowd, M. (1997). On predicting the growth of cultured bivalves. Ecological Modelling 140:113-131.

Dowd, M. (2005). A bio-physical coastal ecosystem model for assessing environmental effects of marine bivalve aquaculture. Ecological Modelling 183:323346.

Dzombak DA, Morel FMM. 1990. Surface complexation modelling: Hydrous ferric oxide. New York, John Wiley \& Sons.

Eisler R. 1998. Copper hazards to fish, wildlife and invertebrates: a synoptic review. US Dept. of Commerce, USGS/BRD/BSR - 1997 - 0002 Springfield. 1-98.

Eyre BD, McKee LJ. 2002. Carbon, nitrogen, and phosphorus budgets for a shallow subtropical coastal embayment (Moreton Bay, Australia). Limnology and Oceanography 47:1043-1055.

González-Dávila M, Santana-Casiano JM, Perez-Pena J, Millero FJ. 1995. Binding of 
$\mathrm{Cu}(\mathrm{II})$ to the surface and exudates of the alga Dunaliella tertiolecta in seawater. Environmental Science and Technology 29:289-301.

González-Dávila M, Santana-Casiano JM, Laglera LM. 2000. Copper adsorption in diatom cultures. Marine Chemistry 70:161-170.

Goulet RR, Krack S, Doyle PJ, Hare L, Vigneault B, McGeer JC. 2007. Dynamic multipathway modeling of Cd bioaccumulation in Daphnia magna using waterborne and dietborne exposures. Aquatic Toxicology 81:117-125.

Håkanson L, Brittain JE, Monte L, Heling R, Bergström U. (1996). Modelling of Radiocesium in Lakes - the VAMP. Journal of Environmental Radioactivity 33:255308.

He M, Wang Z, Tang H. 2001. Modelling the ecological impact of heavy metals on aquatic ecosystems: a framework for the development of an ecological model. Science of the Total Environment 266:291-298.

Hirose K. 1994. Conditional stability constants of metal complexes of organic ligands in sea water: past and present, and a simple coordination chemistry model. Analytica Chimica Acta 284:621-634.

Ihaka R, Gentleman R. 1996. R: a language for data analysis and graphics. J Comput Graphical Statist 5: 299-314. 
Jackson JBC, Kirby MX, Berger WH, Bjorndal KA, Botsford LW, Bourque BJ, Bradbury RH, Cooke R, Erlandson J, Esters JA, Hughes TP, Kidwell S, Lange CB, Lenihan HS, Pandolfi JM, Peterson CH, Steneek RS, Tegner MJ, Warner RR. 2001. Historical overfishing and the recent collapse of coastal ecosystems. Science 293:629638.

Kim E, Mason RP, Bergeron CM. 2008. A modeling study on methylmercury bioaccumulation and its controlling factors. Ecological Modelling 218:267-289.

Koelmans AA, van der Heijde A, Knijff LM, Aalderink RH. 2001. Integrated Modelling of Eutrophication and Organic Contaminant Fate \& Effects In Aquatic Ecosystems. A Review. Water Research 35:3517-3536.

Lee RW and Rust W. 1997. Light attenuation in a shallow, turbid reservoir, Lake Houston Texas. US Geological Survey: Water Resources Investigation Report 974064.

Liao C-M, Chen B-C, Lin M-C, Chen J-W. 2002. An optimal trace zinc biomonitor (Haliotis diversicolor supertexta) control system design in aquacultural ecosystems, Applied Mathematical Modelling 24:27-43.

Luoma SN and Rainbow PS. 2005. Why is Metal Bioaccumulation so Variable? Biodynamics as a Unifying Concept. Environmental Science and Technology 39(7):1921-1931. 
Martell AE, Motekaitis RJ. 1988. Determination and use of stability constants. New York, VCH.

McEwan J. 1996. A coupled hydrodynamic, transport and kinetic model of eutrophication processes in Moreton Bay, Queensland. Department of Chemical Engineering. Brisbane, University of Queensland.

Moffett JW, Brand LE, Croot PL, Barbeau KA. 1997. 1 Cu speciation and cyanobacterial distribution in harbors subject to anthropogenic Cu inputs. Limnology and Oceanography 42:789-799.

Monte L, Brittain JE, Håkanson L, Heling R, Smith JT, Zheleznyak M. (2003). Review and assessment of models used to predict the fate of radionuclides in lakes. Journal of Environmental Radioactivity 69:177-205.

Monte L, Periañez R, Boyer P, Smith JT, Brittain JE. (2009a). The role of physical processes controlling the behaviour of radionuclide contaminants in the aquatic environment: a review of state-of-the-art modelling approaches. Journal of Environmental Radioactivity 100:779-784.

Monte L, Brittain JE, Gallego E, Håkanson L, Hofman D, Jiménez A. (2009b). MOIRA-PLUS: A decision support system for the management of complex fresh water ecosystems contaminated by radionuclides and heavy metals. Computers \& Geosciences 35:880-896. 
Morel F. 1983. Principles of aquatic chemistry. New York. John Wiley \& Sons.

Mubiana VK, Blust R. 2007. Effects of temperature on scope for growth and accumulation of $\mathrm{Cd}, \mathrm{Co}, \mathrm{Cu}$ and $\mathrm{Pb}$ by the marine bivalve Mytilus edulis. Marine Environmental Research 63: 219-35.

Murray AG, Parslow JS. 1999. Modelling of nutrient impacts in Port Phillip Bay - a semi-enclosed marine Australian ecosystem. Marine and Freshwater Research 50:597611.

Paquin PR, Gorsuch JW, Apte S, Batley GE, Bowles KC, Campbell PGC, Delos CG, Di Toro DM, Dwyer RL, Galvez F, Gensemer RW, Goss GG, Hogstrand C, Janssen CR, McGeer JC, Naddy RB, Playle RC, Santore RC, Schneider U, Stubblefield WA, Wood CM, Wu KB. 2002. The biotic ligand model: a historical overview. Comparative Biochemistry and Physiology Part C 133:3-35.

Parkhurst, DL, Appelo, CAJ. 1999. User’s guide to PHREEQC (version 2) - A computer program for speciation, batch-reaction, one-dimensional transport, and inverse geochemical calculations. Water Resources Investigations Report 99-4259. US Deptartment of Interior US Geological Survey. Denver Colarado.

Parslow J, Hunter J, Davidson, A. 1999. Estuarine Eutrophication Models. Final Report Project E6 National River Health Program. Water Services Association of Australia Melbourne Australia. CSIRO Marine Research, Hobart Tasmania. Report No.12, LWRRDC Occasional Paper 19/99. 
Paulson AJ, Kester DR. 1980. Copper(II) Ion Hydrolysis in 1 Aqueous Solutions. Journal of Solution Chemistry 9:269-277.

Phillips DJH. 1980. Quantitative Aquatice Biological Indicators. London, Applied Science Publishers.

Reinfelder JR, Wang W-X, Luoma SN, Fisher NS. 1997. Assimilation efficiencies and turnover rates of trace elements in marine bivalves: a comparison of oysters, clams and mussels, Marine Biology 129:443-452.

R Development Core Team. 2009. R: A language and environment for statistical computing. R Foundation for Statistical Computing, Vienna, Austria. ISBN 3900051-07-0, URL http://www.R-project.org.

Richards R, Chaloupka M. 2009. Temperature-dependent bioaccumulation of copper in an estuarine oyster. Science of the Total Environment 407:5901-5906.

Robinson WA, Maher WA, Krikowa F, Nell JA, Hand R. 2005. The use of the oyster Saccostrea glomerata as a biomonitor of trace metal contamination: Intra-sample, local scale and temporal variability and its implication for biomonitoring. Journal of Environmental Monitoring 7:208-223.

Scott BD. 1978. Phytoplankton distribution and light attenuation in Port Hacking estuary. Australian Journal of Marine and Freshwater Research 29:31-44. 
Shigesada N, Okubo A. 1981. Analyses of the self-shading effect on algal vertical distribution in waters. Journal of Mathematical Biology 12:311-326.

Simon NS. 1989. Nitrogen cycling between sediment and the shallow-water column in the transition zone of the Potomac River and Estuary. II. The role of wind-driven resuspension and adsorbed ammonium. Estuarine, Coastal and Shelf Science 28, 531547.

Steele JH. 1962. Environment control of photosynthesis in the sea. Limnology and Oceanography 7:137-150.

Wang WX, Fisher NS, Luoma SN. 1996. Kinetic determinations of trace element bioaccumulation in the mussel Mytilus edulis. Marine Ecology Progress Series 129:165-176.

van der Lee J. 1998. Thermodynamic and mathematical 1 concepts of CHESS. Technical Report Nr LHM/RD/98/39, Ecole des Mines de Paris, Fontainebleau, France. 


\section{TABLES}

Table 1. Stability constants used in the copper speciation model.

Table 2. State equations of the EBB model.

Table 3. Parameters used in the EBB model.

Table 4. Comparison of EBB speciation calculations versus PHREEQC (Parkhurst and Appelo 1999). Input conditions: $\mathrm{Ca}=1.067 \times 10^{-2} \mathrm{M}, \mathrm{Na}=4.863 \times 10^{-1} \mathrm{M}, \mathrm{C}=$ $1.021 \times 10^{-7} \mathrm{M}, \mathrm{Alg}=2.22 \times 10^{-9} \mathrm{M}, \mathrm{POM}=1.597 \times 10^{-8} \mathrm{M}, \mathrm{HFO} \_\mathrm{sO}=3.195 \times 10^{-8} \mathrm{M}$, $\mathrm{DOM}=3.514 \times 10^{-8} \mathrm{M}, \mathrm{Cu}=3.104 \times 10^{-8} \mathrm{M}$, Ionic strength $=0.64, \mathrm{pH}=8.200$.

Table 5. Bioaccumulation rate constants determined for the five EBB modeling scenarios. 


\begin{tabular}{|c|c|c|}
\hline $\log (\mathbf{K})$ & Equation & Reference \\
\hline 13.998 & $\mathrm{OH}^{-}+\mathrm{H}^{+} \Leftrightarrow \mathrm{H}_{2} \mathrm{O}$ & Dzombak and Morel 1990 \\
\hline 7.29 & Hfo_OH $+\mathrm{H}^{+} \Leftrightarrow$ Hfo_oH ${ }_{2}^{+}$ & Dzombak and Morel 1990 \\
\hline-8.93 & Hfo_OH $\Leftrightarrow$ Hfo_O $\mathrm{O}^{-}+\mathrm{H}^{+}$ & Dzombak and Morel 1990 \\
\hline-5.85 & Hfo_OH $+\mathrm{Ca}^{2+} \Leftrightarrow$ Hfo_OCa ${ }^{+}+\mathrm{H}^{+}$ & Dzombak and Morel 1990 \\
\hline 2.89 & $\mathrm{Hfo} \_\mathrm{OH}+\mathrm{Cu}^{2+} \Leftrightarrow \mathrm{Hfo} \_\mathrm{OCu}^{+}+\mathrm{H}^{+}$ & Dzombak and Morel 1990 \\
\hline 10.75 & $\mathrm{Alg}^{-}+\mathrm{Cu}^{2+} \Leftrightarrow \mathrm{CuAlg}^{+}$ & González-Dávila and others 2000 \\
\hline 10.75 & $\mathrm{POM}^{-}+\mathrm{Cu}^{2+} \Leftrightarrow \mathrm{CuPOM}^{+}$ & González-Dávila and others 2000 \\
\hline 10.82 & $\mathrm{DOM}^{-}+\mathrm{Cu}^{2+} \Leftrightarrow \mathrm{CuDOM}^{+}$ & Moffet and others 1997 \\
\hline 6.00 & $\mathrm{OH}^{-}+\mathrm{Cu}^{2+} \Leftrightarrow \mathrm{CuOH}^{+}$ & Paulson and Kester 1980 \\
\hline 6.73 & $\mathrm{CO}_{3-}{ }^{2+}+\mathrm{Cu}^{2+} \Leftrightarrow \mathrm{CuCO}_{3}$ & Byrne and Miller 1985 \\
\hline
\end{tabular}




\section{Phytoplankton}

$$
\begin{aligned}
& \frac{d\left(P H Y_{1}\right)}{d t}=P H Y_{1} \times\left(\mu_{1}-\text { mort }_{1}\right)+\rho_{1} \times\left(P H Y_{2}-P H Y_{1}\right) \\
& \frac{d\left(P H Y_{2}\right)}{d t}=P H Y_{2} \times\left(\mu_{2}-\text { mort }_{2}\right)+\rho_{1} \times\left(P H Y_{1}-P H Y_{2}\right)+\rho_{2} \times\left(P H Y_{0}-P H Y_{2}\right)
\end{aligned}
$$

\section{DIN}

$$
\begin{aligned}
& \frac{d\left(D I N_{1}\right)}{d t}=D I N_{L O A D, 1}-\mu_{1} \times P H Y_{1}+\min _{20} \times f T \times P O N_{1}+\rho_{1} \times\left(D I N_{2}-D I N_{1}\right) \\
& \frac{d\left(D I N_{2}\right)}{d t}=D I N_{L O A D, 2}-\mu_{2} \times P H Y_{2}+\min _{20} \times f T \times P O N_{2}+\rho_{1} \times\left(D I N_{1}-D I N_{2}\right)+\rho_{2} \times\left(D I N_{0}-D I N_{2}\right)
\end{aligned}
$$

\section{PON}

$$
\begin{aligned}
& \frac{d\left(P N_{1}\right)}{d t}=f P O N \times \text { mort }_{1} \times P H Y_{1}-\min _{20} \times f T \times P O N_{1}+\rho_{1}\left(P O N_{2}-P O N_{1}\right) \\
& \frac{d\left(P O N_{2}\right)}{d t}=f P O N \times \text { mort }_{2} \times P H Y_{2}-\min _{20} \times f T \times P O N_{2}+\rho_{1}\left(P O N_{1}-P O N_{2}\right)+\rho_{2}\left(P O N_{0}-P O N_{2}\right)
\end{aligned}
$$

\section{POM}

$$
\begin{aligned}
& \frac{d\left(P O M_{1}\right)}{d t}=P O M_{S E D} \times R R-S R \times P O M_{1}+\rho_{1} \times\left(P O M_{2}-P O M_{1}\right) \\
& \frac{d\left(P O M_{2}\right)}{d t}=P O M_{S E D} \times R R-S R \times P O M_{2}+\rho_{1} \times\left(P O M_{1}-P O M_{2}\right)+\rho_{2} \times\left(P O M_{0}-P O M_{2}\right)
\end{aligned}
$$

$\mathrm{Cu}_{\mathrm{T}}$

$$
\begin{aligned}
& \frac{d\left(C u_{T, 1}\right)}{d t}=C u_{S E D} \times R R-S R\left(C u_{P O M, 1}+C u_{H F O, 1}\right)+\rho_{1}\left(C u_{T, 2}-C u_{T, 1}\right)+C u_{T, L O A D} \\
& \frac{d\left(C u_{T, 2}\right)}{d t}=C u_{S E D} \times R R-S R\left(C u_{P O M, 2}+C u_{H F O, 2}\right)+\rho_{1}\left(C u_{T, 1}-C u_{T, 2}\right)+\rho_{2}\left(C u_{T, 0}-C u_{T, 2}\right)+C u_{T, L O A D}
\end{aligned}
$$

\section{Cu-Oyster}

$$
\frac{d\left(C u_{O Y S, 1}\right)}{d t}=k_{u(20)} \times f T \times C u_{W}-k_{e} \times C u_{O Y S, 1}
$$




$$
\frac{d\left(C u_{O Y S, 2}\right)}{d t}=k_{u(20)} \times f T \times C u_{W}-k_{e} \times C u_{O Y S, 2}
$$




\begin{tabular}{|c|c|c|c|}
\hline Parameter & Description & Value & Reference \\
\hline \multicolumn{4}{|c|}{ Phytoplankton Model } \\
\hline $\mathrm{T}_{\mathrm{AVE}}$ & Average annual temperature $\left({ }^{\circ} \mathrm{C}\right)$ & 20 & EHMP 2008 \\
\hline $\mathrm{T}_{\text {RANGE }}$ & Annual temperature range $\left({ }^{\circ} \mathrm{C}\right)$ & 10.59 & EHMP 2008 \\
\hline time $_{\mathrm{LAG}}$ & Time lag between Julian day and temp. (d) & 70 & Calibrated \\
\hline$\theta$ & Temperature adjustment coefficient & 1.008 & Bowie and others 1985 \\
\hline PHY $_{\text {OCEAN }}$ & Oceanic concentration (mg-N m${ }^{-3}$ ) & 0.5 & EHMP 2008 \\
\hline POM $_{\text {OCEAN }}$ & Oceanic concentration $\left(\mathrm{mg}-\mathrm{m}^{-3}\right)$ & 500 & this study \\
\hline PON $_{\text {OCEAN }}$ & Oceanic concentration (mg-N m${ }^{-3}$ ) & 1 & EHMP 2008 \\
\hline DIN OCEAN & Oceanic concentration (mg-N m ${ }^{-3}$ ) & 0.75 & EHMP 2008 \\
\hline $\mathrm{N}:$ Chla & Phytoplankton $\mathrm{N}$ to Chla ratio & 0.7227 & Bowie and others 1985 \\
\hline Phy:N & Phytoplankton biomass to $\mathrm{N}$ ratio & 0.051 & Bowie and others 1985 \\
\hline DIN:TN & DN to total $\mathrm{N}$ ratio & 0.03 & EHMP 2008 \\
\hline$\mu_{\mathrm{MAX}}$ & Maximum phyto growth rate, $20^{\circ} \mathrm{C}\left(\mathrm{d}^{-1}\right)$ & 1.5 & Bowie and others 1985 \\
\hline $\mathrm{K}_{\text {DIN }}$ & Half-saturation conc. - DIN uptake ( $\left.\mathrm{mg} \mathrm{m}^{-3}\right)$ & 25 & Bowie and others 1985 \\
\hline $\mathrm{I}_{\mathrm{K}}$ & Half-saturation - light intensity $\left(\mathrm{MJ} \mathrm{m}^{-2} \mathrm{~s}^{-1}\right)$ & 1.139 & Arhonditsis and others 2008 \\
\hline$\lambda_{\text {CHLA }}$ & $\begin{array}{l}\text { Light extinct. coeff. - phytoplankton ([L( } \mu \mathrm{g} \\
\left.\text { chla m })^{-1}\right] \text { ) }\end{array}$ & 0.046 & Arhonditsis and others 2008 \\
\hline$\lambda_{0}$ & Background light extinction coeff $\left(\mathrm{m}^{-1}\right)$ & 1.18 & Calibrated \\
\hline $\mathrm{m}_{20}$ & Background mortality rate, $20^{\circ} \mathrm{C}\left(\mathrm{d}^{-1}\right)$ & 0.003 & Calibrated \\
\hline fPON & Labile fraction of PON & 0.3 & Arhonditsis and others 2008 \\
\hline $\mathrm{m}_{1}$ & Maximum grazing loss rate $\left(\mathrm{d}^{-1}\right)$ & 0.4 & Parslow and others 1999 \\
\hline $\mathrm{k}_{\mathrm{P}}$ & $\begin{array}{l}\text { Phyto conc corresponding to maximum } \\
\text { grazing loss rate }\left(\mathrm{mg}-\mathrm{N} \mathrm{m}^{-3}\right)\end{array}$ & 20 & Parslow and others 1999 \\
\hline $\min _{20}$ & Mineralization rate, $20^{\circ} \mathrm{C}\left(\mathrm{d}^{-1}\right)$ & 0.017 & Calibrated \\
\hline SR & Settling rate $\left(\mathrm{m} \mathrm{d}^{-1}\right)$ & 0.06 & Calibrated \\
\hline $\mathrm{RR}$ & Resuspension rate $\left(\mathrm{m} \mathrm{d}^{-1}\right)$ & $1.21 \mathrm{E}-6$ & Calibrated \\
\hline $\mathrm{POM}_{\mathrm{SED}}$ & POM concentration in sediment $\left(\mathrm{mg} \mathrm{m}^{-3}\right)$ & 9.19E7 & Burton and others 2005 \\
\hline $\mathrm{z}_{1}$ & Depth of Box 1 (m) & 4.9 & Bell and Amghar 2001 \\
\hline $\mathrm{z}_{2}$ & Depth of Box 2 (m) & 9.6 & Bell and Amghar 2001 \\
\hline$\rho_{1}$ & Exchange rate between boxes 1 and $2\left(\mathrm{~d}^{-1}\right)$ & 0.017 & Dennison and Abal 1999 \\
\hline & Oceanic exchange rate $\left(\mathrm{d}^{-1}\right)$ & 0.018 & Dennison and Abal 1999 \\
\hline \multicolumn{4}{|c|}{ Copper Speciation Model } \\
\hline $\mathrm{Cu}_{\mathrm{LOAD}}$ & Copper load into Moreton Bay $\left(\mathrm{mg} \mathrm{m}^{-3} \mathrm{~d}^{-1}\right)$ & 0.02 & Calibrated \\
\hline $\mathrm{Cu}_{\text {OCEAN }}$ & Oceanic concentration $\left(\mathrm{mg} \mathrm{m}^{-3}\right)$ & 0.5 & Assumed \\
\hline $\mathrm{Cu}_{\text {SED1 }}$ & $\mathrm{Cu}$ sediment concentration - Box $1\left(\mathrm{mg} \mathrm{m}^{-3}\right)$ & 12700 & Burton and others 2005 \\
\hline $\mathrm{Cu}_{\mathrm{SED} 2}$ & Cu sediment concentration - Box $2\left(\mathrm{mg} \mathrm{m}^{-3}\right)$ & 12300 & Burton and others 2004 \\
\hline$\beta$ & $\begin{array}{l}\text { Density of biogenic adsorption sites (mol g- } \\
{ }^{1} \text { ) }\end{array}$ & $6.25 \times 10^{-6}$ & $\begin{array}{l}\text { González-Dávila and others } \\
2000\end{array}$ \\
\hline HFO_O- & $\begin{array}{l}\text { Density of } \mathrm{Cu} \text { adsorption sites - hydrous } \\
\text { ferrous oxide (sites [mole } \mathrm{Fe}]^{-1} \text { ) }\end{array}$ & $5 \times 10^{-6}$ & Dzombak and Morel 1990 \\
\hline DOM- & Dissolved organic ligands (moles $\mathrm{m}^{-3}$ ) & $2.9 \times 10^{-5}$ & Calibrated \\
\hline$\eta$ & Sorption factor - phytoplankton cells & 9 & Chang and Reinfelder 2000 \\
\hline
\end{tabular}




\begin{tabular}{|c|c|c|}
\hline \multirow[t]{2}{*}{ Species } & \multicolumn{2}{|c|}{ Concentration (M) } \\
\hline & EBB & PHREEQC \\
\hline $\mathrm{Cu}^{2+}$ & $1.1 \mathrm{E}-10$ & $1.2 \mathrm{E}-10$ \\
\hline $\mathrm{Hfo} \mathrm{OCu}^{+}$ & 2.8E-09 & 1.6E-09 \\
\hline $\mathrm{CuAlg}^{+}$ & $8.6 E-10$ & $9.3 \mathrm{E}-10$ \\
\hline $\mathrm{CuPOM}^{+}$ & $6.2 \mathrm{E}-09$ & 6.7E-09 \\
\hline $\mathrm{CuDOM}^{+}$ & $1.5 \mathrm{E}-08$ & 1.6E-08 \\
\hline $\mathrm{Cu}_{\text {Particulate }}$ & 2.5E-08 & 2.5E-08 \\
\hline $\mathrm{Cu}_{\text {Dissolved }}$ & $6.1 \mathrm{E}-09$ & 5.7E-09 \\
\hline
\end{tabular}




\begin{tabular}{|c|c|c|c|}
\hline Scenario & Copper species used & $\begin{array}{c}\mathbf{k}_{\mathrm{u}, 20} \\
\left(\mathbf{l ~ g}^{-1} \mathbf{d}^{-1}\right)\end{array}$ & $\begin{array}{c}\mathbf{k}_{\mathbf{e}} \\
\left(\mathbf{d}^{-1}\right)\end{array}$ \\
\hline 1 & Cu-Phyto & 23.29 & 0.0059 \\
\hline 2 & Cu-Phyto + Cu-POM & 3.222 & 0.0096 \\
\hline 3 & Cu-Phyto + Cu-POM + Cu-HFO & 1.891 & 0.0096 \\
\hline 4 & $\mathrm{Cu}_{\mathrm{T}}$ & 0.9635 & 0.0105 \\
\hline 5 & $\mathrm{Cu}^{2+}$ & $1.049 \mathrm{E} 6$ & 0.0113 \\
\hline
\end{tabular}


Figure 1. Conceptualisation of the EBB model.

Figure 2. Study site location, box model regions and monitoring locations $\left({ }^{*}\right)$ used in this study.

Figure 3. Predicted (-) and measured (*:mean \pm 1 SD) concentrations for chlorophylla (top), dissolved inorganic nitrogen (middle) and particulate organic matter (bottom). Figure 4. Predicted (-) and measured (*) concentrations for total copper (top), particulate copper (middle) and dissolved copper (bottom).

Figure 5. Predicted and measured oyster copper concentrations for different uptake pathways.

Figure 6. Comparisons of predicted $(+1 \mathrm{SD})$ soft-tissue Cu concentrations ( $\mu \mathrm{g} \mathrm{g}^{-1}$, dry weight basis) against actual measured concentrations for different $\mathrm{Cu}$ uptake pathways. $\boldsymbol{\square}$ indicates Box 1 and $\boldsymbol{\Delta}$ indicates Box 2. The diagonal line through each graph indicates a 1:1 line. 


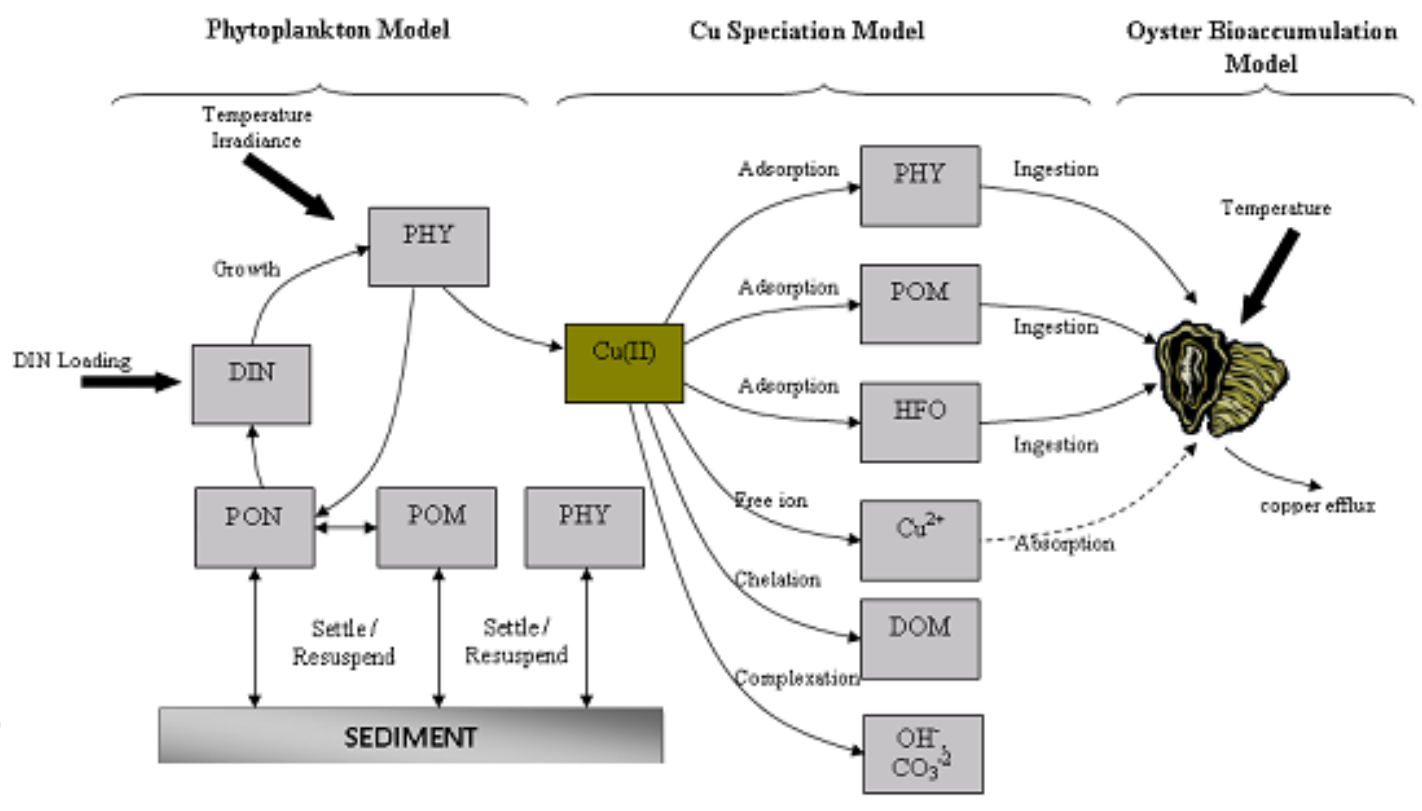




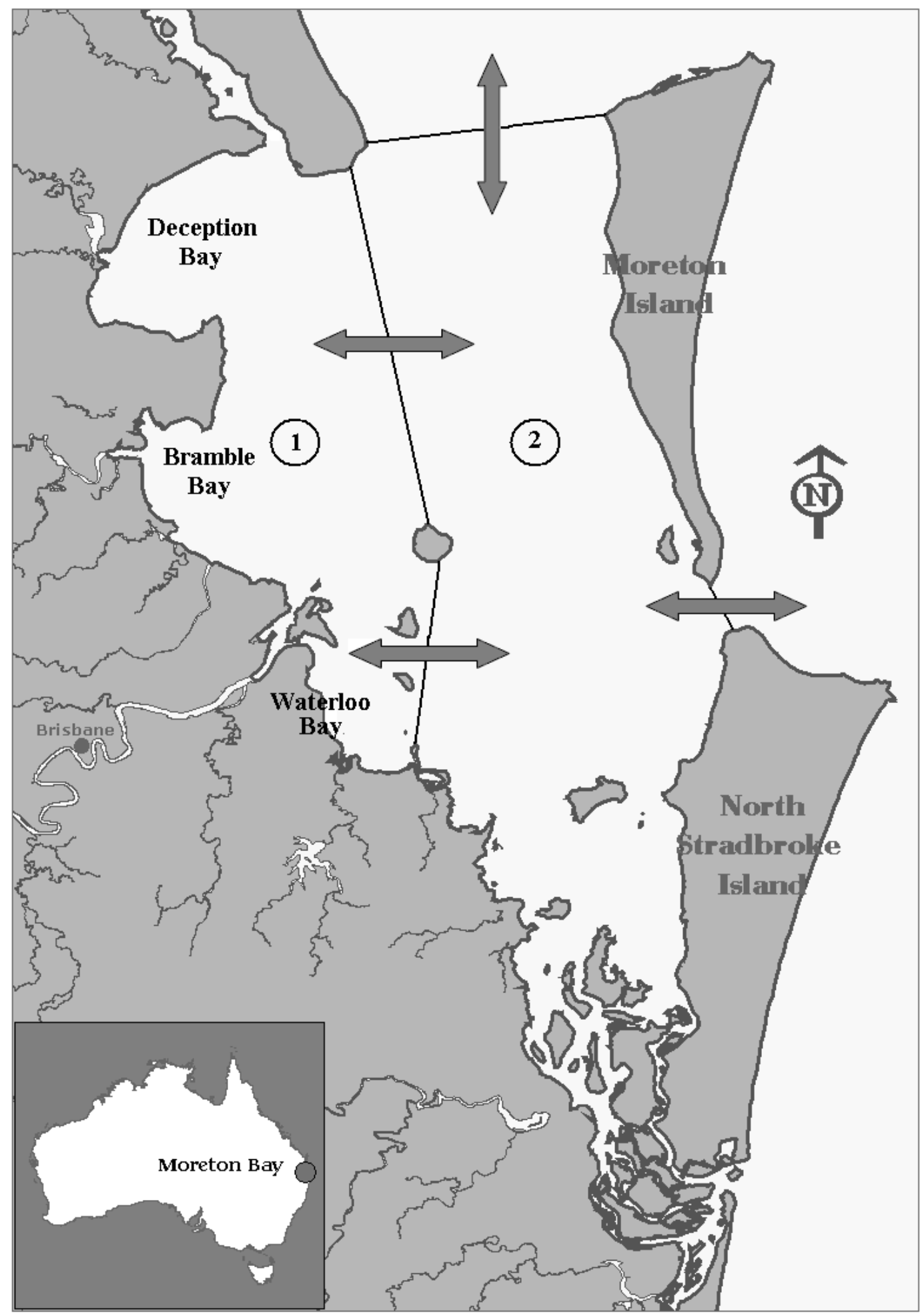


(a.)

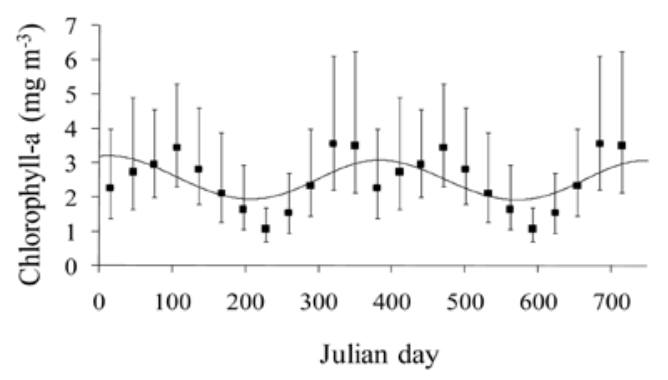

(c.)

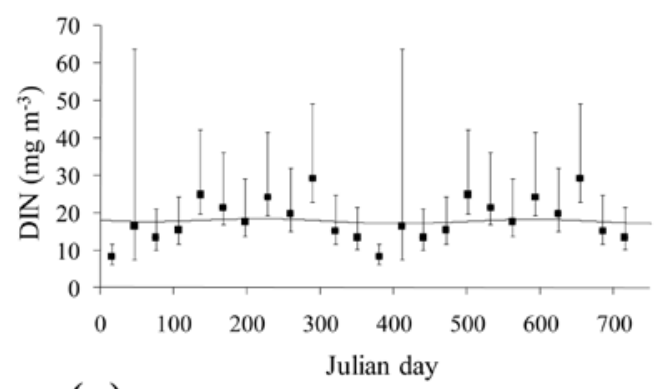

(e.)

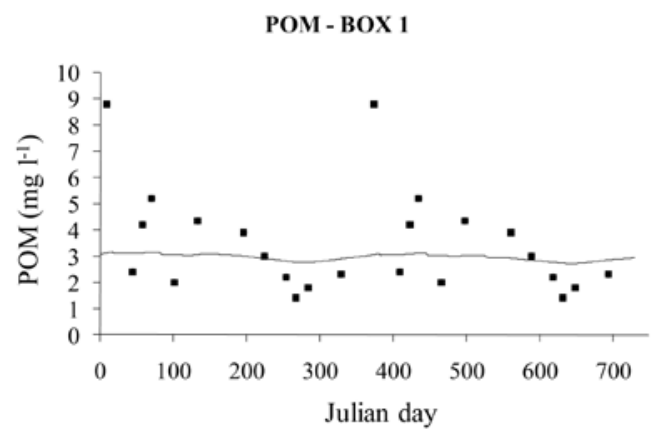

(b.)

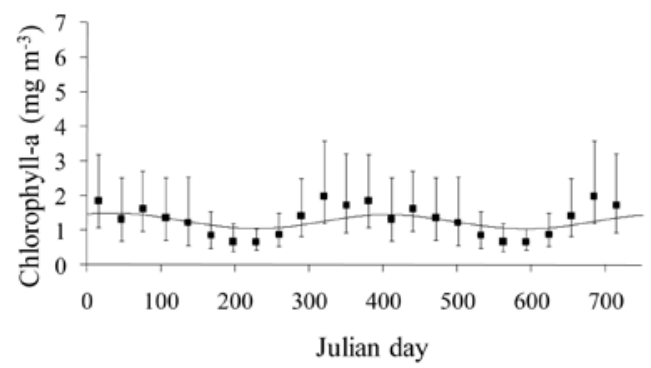

(d.)

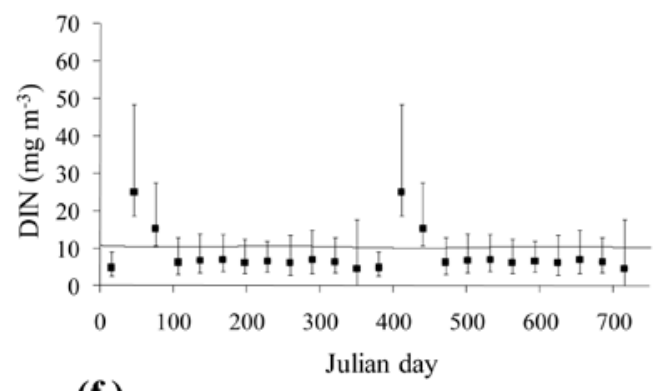

(f.)

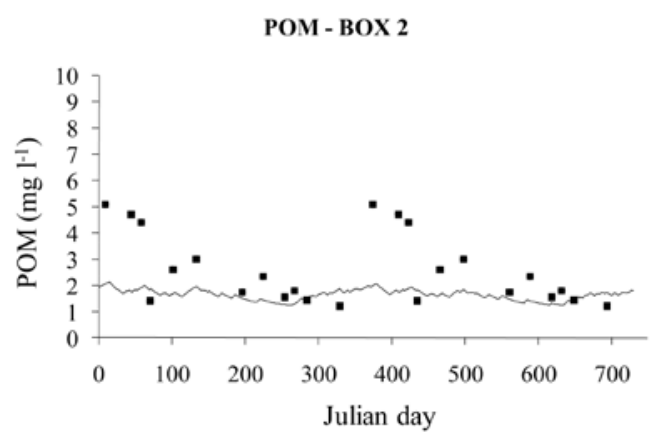


(a.)

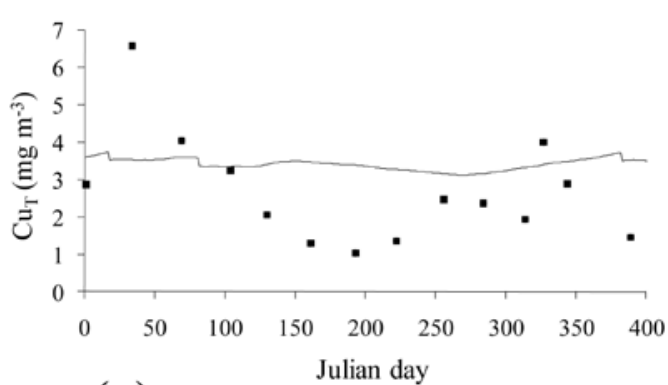

(c.)

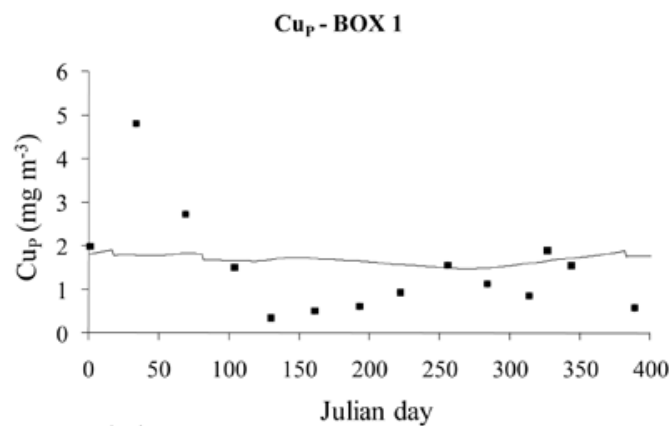

(e.)

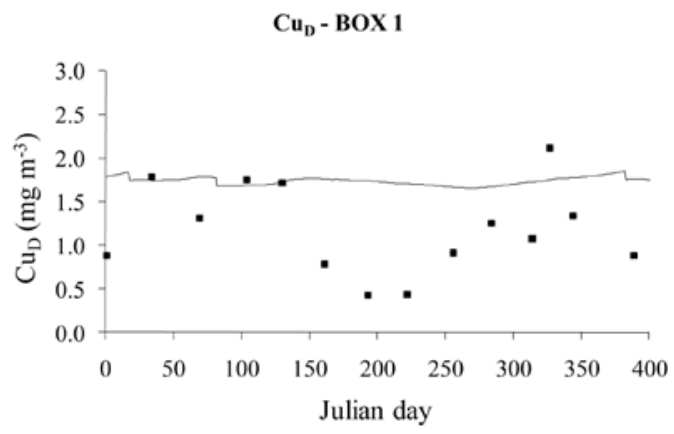

(b.)

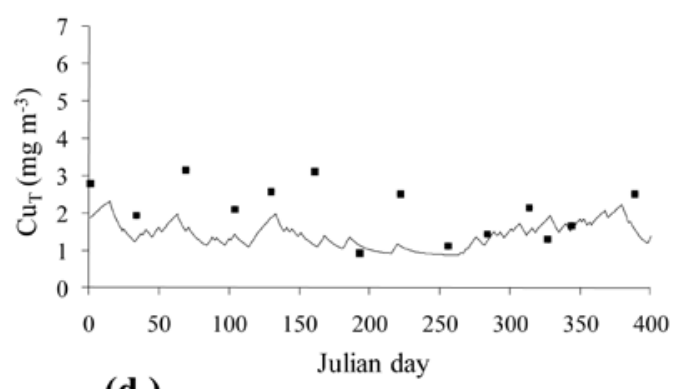

(d.)

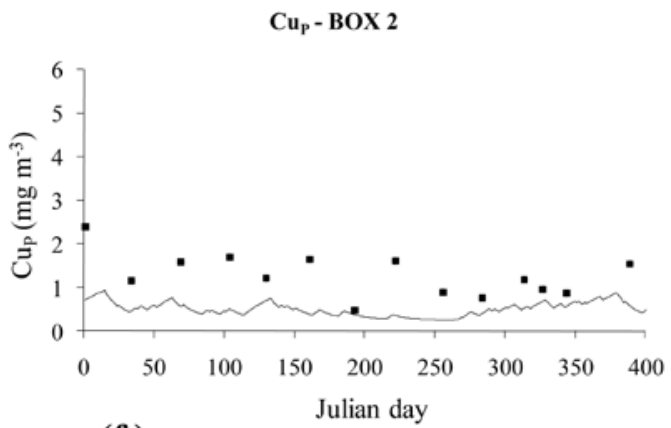

(f.)

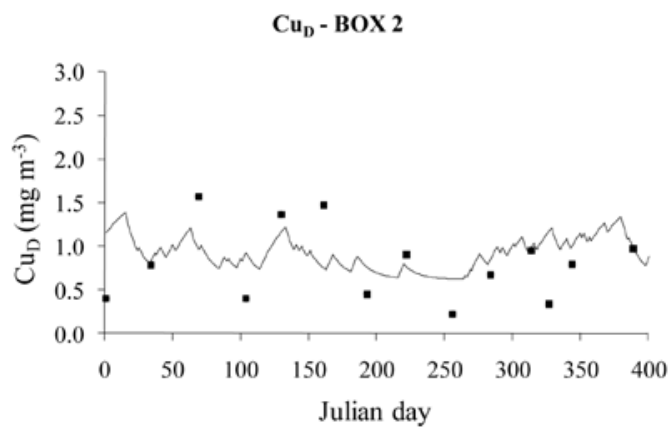


(a.)

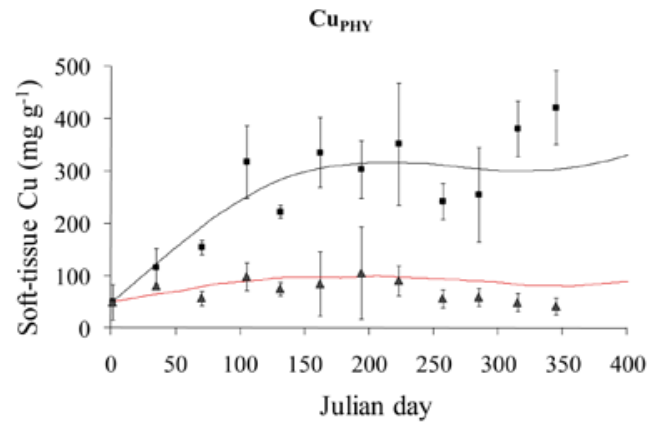

(c.)

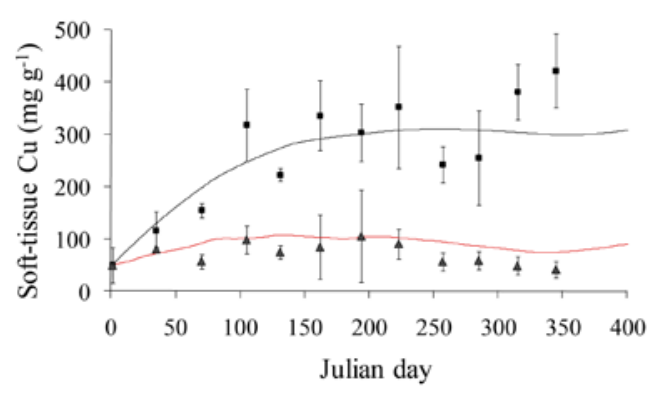

(e.)

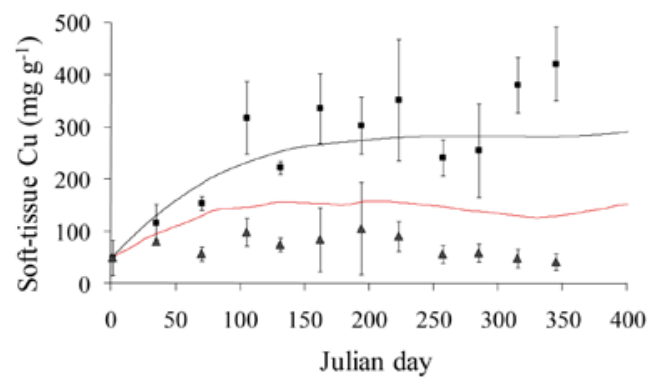

(b.)

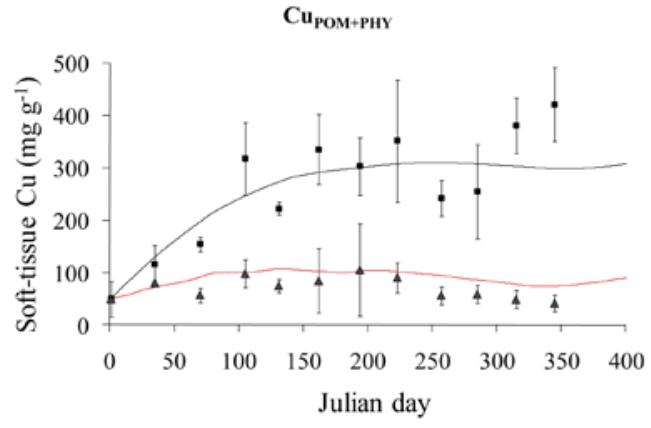

(d.)

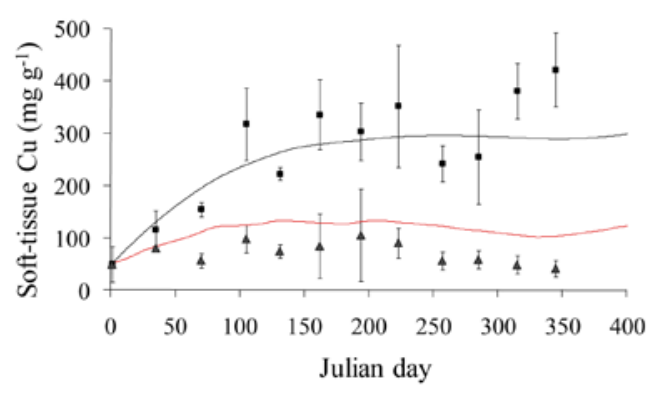


(a.)

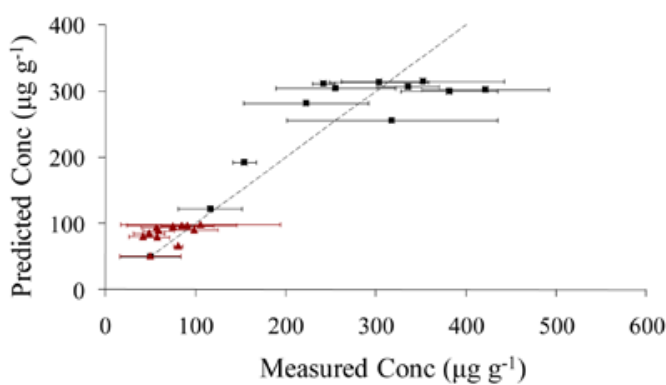

(c.)

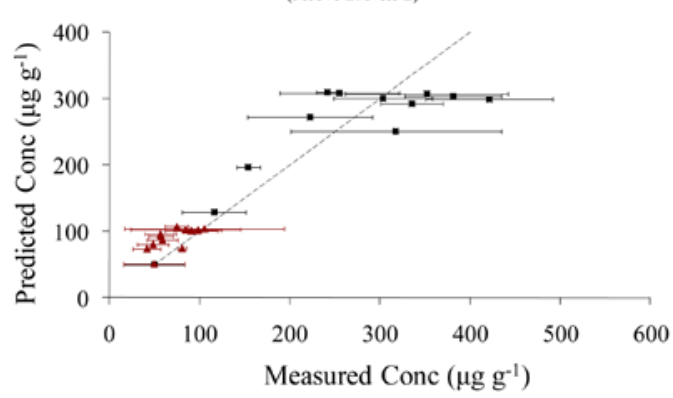

(e.)

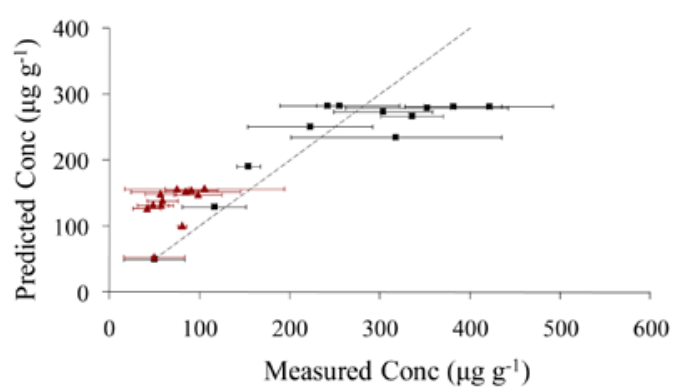

(b.)

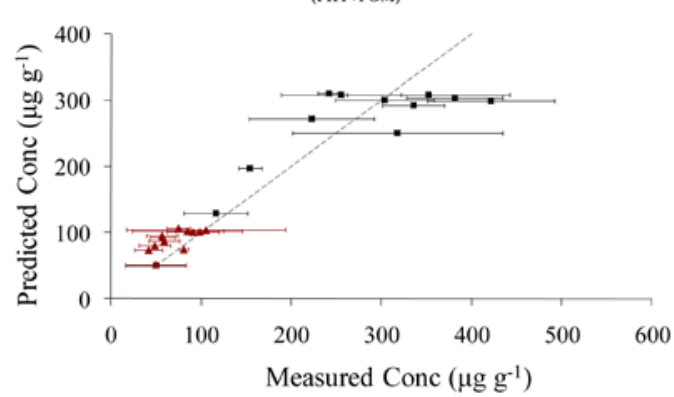

(d.)

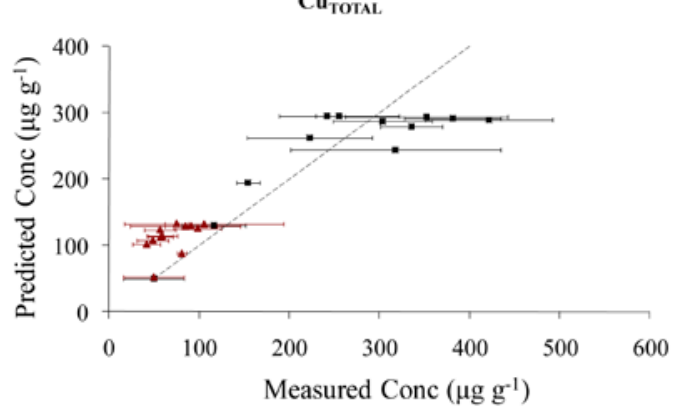

